\title{
Mini-Review on Domination of Pollutant Residues Among Food Products: Perspective of South-East Asian Countries
}

\author{
A. K. Mohiuddin*
}

\begin{abstract}
Southeast Asia is a region that produces high amounts of key food commodities and includes areas of divergent socioeconomic status. Food security is a high-priority issue for sustainable global development both quantitatively and qualitatively. In recent decades, the adverse effects of unexpected contaminants on crop quality have threatened both food security and human health. Public concern about the adverse environmental and human health impacts of organochlorine contaminants led to strict regulations on their use in developed nations two decades ago. Nevertheless, DDT and several other organochlorine insecticides are still being used for agriculture and public health programs in developing countries in Asia and the South Pacific. As a consequence, humans in this region are exposed to greater dietary levels of organochlorines. Heavy metals and metalloids ( $\mathrm{Hg}, \mathrm{As}, \mathrm{Pb}, \mathrm{Cd}$ and Cr) can jeopardize human metabolomics, contributing to morbidity and even mortality. This review indicates potential contaminants associated with crop production process through soil nutrient depletion, water depletion, soil and water
\end{abstract}

Department of Pharmacy, World University of Bangladesh, 151/8, Green Road, Dhanmondi, Dhaka-1205, Bangladesh

*mohiuddin3@pharmacy.wub.edu.bd

https://orcid.org/0000-0003-1596-9757

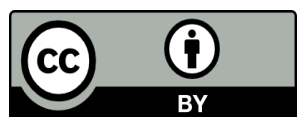

This article is published under the Creative Commons Attribution License (CC 4.0),

which permits unrestricted use, distribution, and reproduction in any medium provided the original work is properly cited. contamination, and pest resistance/ outbreaks and the emergence of new pests and diseases.

Keywords: Fertilizers, Food processing, Heavy metal poisoning, Organochlorine insecticides, Pesticides

\section{INTRODUCTION}

Growth in global population means that farmers must produce food for an estimated 9.1 billion people expected to inhabit the earth by 2050 (Rahaman et al., 2018). Globally, there are over 50,000 edible plants. Just three of these (rice, maize and wheat) provide about $60 \%$ of the world's food energy intake (Thielecke et al., 2018). The countries of South and Southeast Asia span an area of about 9.75 million $\mathrm{km}^{2}$ and have a population of 2.4 billion. According to Sabir et al. (2019) almost $30.66 \%$ of the world's population is represented in only $6.57 \%$ of the world's land area. According to the World Bank, South Asian countries are home to $33 \%$ of the world's poor and their economies have among the highest levels of public debt in the world (Schafer, 2019).

The mean consumption of whole grains in the world was $38.4 \mathrm{~g} /$ day in between 1990 to 2010. Southeast Asian nations along with 2/3 Sub-Saharan African regions had the highest intakes. Overall, 23 of 187 countries had mean whole-grain 
intake $\geq 2.5$ (50 g) servings/day, representing 335 million adults and $7.6 \%$ of the world adult population (Micha et al., 2015). Southeast Asia is a region that produces high amounts of key food commodities and includes areas of divergent socioeconomic status. The major grain crops produced in the region are rice and maize (Brownlee et al., 2018). The potential sources for the contamination of grains are mostly environmentally based and include air, dust, soil, water, insects, rodents, birds, animals, microbes, humans, storage and shipping containers, and handling and processing equipment (Brar and Danyluk, 2018).

Plants are the world's major source of food. These plants are susceptible to 80,000 to 100,000 diseases caused by everything from viruses to bacteria, fungi, algae, and even other higher plants. Humans cultivate only about 150 of an estimated 30,000 edible plant species worldwide, with only 30 plant species comprising the vast majority of our diets (Shelef et al., 2017). Again, food plants have to compete with some 30,000 different species of weeds worldwide, of which at least 1800 species are capable of causing serious economic losses (Robson et al., 2012). Globally, around $20-30 \%$ of agricultural produce is lost annually due to insect pests, diseases, weeds and rodents during growth, harvest, and storage (Rahaman et al., 2018). The rates of destruction often are higher in less developed nations and they are now accounting for a quarter of the world's pesticide use (Robson et al., 2012).
Therefore, the judicious use of pesticides plays a major role in plant protection.

\section{POTENTIAL SOURCES OF CHEMICAL CONTAMINANTS}

Contamination by chemicals from the environment include metals/metalloids, polycyclic aromatic hydrocarbons (PAHs), persistent organic pollutants (POPs), perfluorinated compounds (PFCs), pharmaceutical and personal care products (PPCPs), radioactive elements, electronic waste, plastics, and nanoparticles (Thompson et al., 2019). At the same time, agricultural land has been used for estate or factory development resulting in pollution of the land and water (Tong and Wenjie, 2015). In managed ecosystems such as those in cultivation for food crops, on the other hand, conditions are often manipulated to maximize crop yields through irrigation and fertilization (Tie et al., 2016). Research has clearly identified environmental harm from the presence of micropollutants in soils, groundwater and surface water. Surface water was found to be more contaminated than groundwater with a greater number of and more concentrated pesticides (organochlorines and organophosphates) (Lari et al., 2014).

Farmers habitually apply fertilizers and hazardous insecticides in high quantities without assessing the actual field requirements due to inadequate knowledge (Rahaman et al., 2018; Mabe et al., 2017). Since pesticides are directly applied on crops, fruits, and vegetables in most agricultural applications, infants, children, 
and adults can be exposed to pesticides by the ingestion of those pesticidecontaminated foods (Roberts et al., 2012; National Research Council, 1993). Pesticides can exist in residential air by the evaporation of volatile and semi-volatile pesticides, such as organochlorine pesticides, from crops and residential surface soil (Li and Jennings, 2017; Mai et al., 2016).

Soil is an important source for heavy metals (like mercury/cadmium) in crops and vegetables since the plants' roots can absorb these pollutants from soil, and transfer them to seeds (Zhang et al., 2015; Li el at., 2017). According to RetamalSalgado et al. (2017), cadmium (Cd) distribution in the different plant organs, more than $40 \%$ of $\mathrm{Cd}$ is absorbed and translocated to the aerial part of the plant (grain and straw), and it could be directly (grains) or indirectly (animals) ingested and negatively affected humans. It accumulates in the liver and kidneys for more than 30 years and causes health problems. Toxicity of this metal involves kidney and skeletal organs and is largely the result of interactions between $\mathrm{Cd}$ and essential metals, such as calcium (Rodríguez and Mandalunis, 2018; Jan et al., 2015). Hassan et al. (2017) say an increased prevalence of diabetes in South Asia may be related to the consumption of arsenic-contaminated rice depending on its content in the rice and the daily amount consumed. Sabir et al. (2019) demonstrated that arsenite can bind covalently with sulfhydryl groups in insulin molecules and receptors, enzymes such as pyruvate dehydrogenase and alpha keto- glutarate dehydrogenase, and glucose transporters (GLU-T), which may result in insulin resistance.

China feeds $22 \%$ of the world population with $7 \%$ of the world's arable land. Sodango et al. (2018) reported that 20 million hectares (approximately 16.1\%) of the total arable land in China is highly polluted with heavy metals, according to the Ministry of Environmental Protection (MEP), China. It is estimated that between 900,000 and 1,360,000 kg arsenic per year was introduced into Bangladesh soil through contaminated groundwater used for irrigation (McCarty et al., 2011). PajewskaSzmyt et al. (2019) reported that maternal exposure to heavy metals as $\mathrm{Pb}$ or $\mathrm{Hg}$ and persistent organic pollutants were associated with children's neurodevelopment delay and also indirectly affects the reproductive, respiratory, and endocrine systems.

The US Centre for Disease Control and Prevention confirmed more than 11,000 foodborne infections in the year 2013, with several agents like viruses, bacteria, toxins, parasites, metals, and other chemicals causing food contamination (Rather et al., 2017). Widespread agricultural use of pesticides and home storage make them easily available for acts of self-harm in many rural households. Stability of organophosphorus pesticides is also an important issue (Guo et al., 2018). It was found that malathion was more unstable than dichlorvos and diazinon, there was an over $70 \%$ loss in 90 days even at $-20{ }^{\circ} \mathrm{C}$ in a coarsely chopped form (Bian et al., 2018). It could be another reason for the haphazard 
use of pesticides in the field and stored food commodities (Thapa et al., 2015). Around 600 million foodborne illnesses and 420,000 deaths occur each year due to poor food handling practice. Such contaminants get access to contaminate food mainly due to food handler's poor knowledge and negligence during handling activities (Chekol et al., 2019; Tegegne and Phyo, 2017). The washing with water or soaking in solutions of salt and some chemicals e.g. chlorine, chlorine dioxide, hydrogen peroxide, ozone, acetic acid, hydroxy peracetic acid, iprodione and detergents are reported to be highly effective in reducing the level of pesticides (Bajwa and Sandhu, 2014). Various food-processing operations include sorting, trimming, cleaning, cooking, baking, frying, roasting, flaking, and extrusion that have variable effects on mycotoxins (Kaushik, 2015). Cooking rice in excess water efficiently reduces the amount of arsenic (As) in the cooked grain (Gray et al., 2016).

\section{ACKNOWLEDGMENTS}

The author thanks Dr. Hui Key Lee, Institute of Biological Sciences, Faculty of Science, University of Malaya, Kuala Lumpur, Malaysia for giving valuable suggestions and for the Seminar Library of Faculty of Pharmacy, University of Dhaka and BANSDOC Library, Bangladesh for providing books, journal and newsletters.

\section{ABBREVIATIONS}

Polycyclic Aromatic Hydrocarbons (PAHs); Persistent Organic Pollutants
(POPs); Per-Fluorinated Compounds (PFCs); Pharmaceutical and Personal Care Products (PPCPs); International Food Policy Research Institute (IFPRI); Ministry of Environmental Protection (MEP).

\section{REFERENCES}

Bajwa, U. and Sandhu, K.S., (2014). Effect of Handling and Processing on Pesticide Residues in Food-a Review. Journal of Food Science and Technology, 51(2): 201-220.

Bian, Y., Liu, F., Chen, F. and Sun, P., (2018). Storage Stability of Three Organophosphorus Pesticides on Cucumber Samples for Analysis. Food Chemistry, 250: 230-235.

Brar, P.K. and Danyluk, M.D., (2018). Nuts and Grains: Microbiology and Preharvest Contamination Risks. Microbiolspec, doi:10.1128/microbiolspec.PFS-00232018

Brownlee, I.A., Durukan, E., Masset, G., Hopkins, S. and Tee, E., (2018). An Overview of Whole Grain Regulations, Recommendations and Research Across Southeast Asia. Nutrients, 10(6): doi: 10.3390/nu10060752

Chekol, F.A., Melak, M.F., Belew, A.K. and Zeleke, E.G., (2019). Food handling Practice and Associated Factors Among Food Handlers in Public Food Establishments, Northwest Ethiopia. BMC research notes, 12(1): 20. doi:10.1186/s13104-019-4047-0

Gray, P.J., Conklin, S.D., Todorov, T.I. and Kasko, S.M., (2016). Cooking Rice in Excess Water Reduces Both Arsenic and Enriched Vitamins in the Cooked Grain. Food Additives and Contaminants: Part A, 33(1): 78-85.

Guo, G., Jiang, N., Liu, F. and Bian, Y., (2018). Storage Stability of 
Organophosphorus Pesticide Residues in Peanut and Soya Bean Extracted Solutions. Royal Society Open Science, 5(7): 180757.

Hassan, F.I., Niaz, K., Khan, F., Maqbool, F. and Abdollahi, M., (2017). The Relation Between Rice Consumption, Arsenic Contamination and Prevalence of Diabetes in South Asia. EXCLI Journal, 16: 1132- 1143.

Jan, A.T., Azam, M., Siddiqui, K., Ali, A., Choi, I. and Haq, Q.M., (2015). Heavy Metals and Human Health: Mechanistic Insight into Toxicity and Counter Defense System of Antioxidants. International Journal of Molecular Sciences, 16(12): 29592-29630.

Kaushik, G., (2015). Effect of Processing on Mycotoxin Content in Grains. Critical Reviews in Food Science and Nutrition, 55(12): 1672-1683.

Lari, S.Z., Khan, N.A., Gandhi, K.N., Meshram, T.S. and Thacker, N.P., (2014). Comparison of Pesticide Residues in Surface Water and Ground Water of Agriculture Intensive Areas. Journal of Environmental Health Science and Engineering, 12(1): doi: 10.1186/2052-336X-12-11.

Li, R., Wu, H., Ding, J., Fu, W., Gan, L. and Li, Y., (2017). Mercury Pollution in Vegetables, Grains and Soils from Areas Surrounding Coal-Fired Power Plants. Scientific Reports, 7 : 46545.

Li, Z. and Jennings, A., (2017). Worldwide Regulations of Standard Values of Pesticides for Human Health Risk Control: A Review. International Journal of Environmental Research and Public Health, 14(7): 826.

Mabe, F.N., Talabi, K. and Danso-Abbeam, G., (2017). Awareness of Health Implications of Agrochemical Use: Effects on Maize Production in EjuraSekyedumase Municipality, Ghana.
Advances in Agriculture, doi.org/10.1155/2017/7960964.

Mai, C., Theobald, N., Hühnerfuss, H. and Lammel, G., (2016). Persistent Organochlorine Pesticides and Polychlorinated Biphenyls in Air of the North Sea Region and Air-Sea Exchange. Environmental Science and Pollution Research, 23(23): 2364823661.

McCarty, K.M., Hanh, H.T. and Kim, K.W., (2011). Arsenic Geochemistry and Human Health in South East Asia. Reviews on Environmental Health, 26(1): 71-78.

Micha, R., Khatibzadeh, S., Shi, P., Andrews, K.G., Engell, R.E. and Mozaffarian, D., (2015). Global, Regional and National Consumption of Major Food Groups in 1990 and 2010: A Systematic Analysis Including 266 Country-Specific Nutrition Surveys Worldwide. BMJ Open, 5(9): doi: 10.1136/bmjopen-2015-008705.

National Research Council, (1993). Pesticides in the Diets of Infants and Children. National Academies Press, United States.

Pajewska-Szmyt, M., Sinkiewicz-Darol, E. and Gadzała-Kopciuch, R., (2019). The Impact of Environmental Pollution on the Quality of Mother's Milk. Environmental Science and Pollution Research, 26(8): 7405-7427.

Rahaman, M.M., Islam, K.S. and Jahan, M., (2018). Rice Farmers' Knowledge of the Risks of Pesticide Use in Bangladesh. Journal of Health and Pollution, 8(20): 181203.

Rather, I.A., Koh, W.Y., Paek, W.K. and Lim, J., (2017). The Sources of Chemical Contaminants in Food and Their Health Implications. Frontiers in Pharmacology, 8: 830.

Retamal-Salgado, J., Hirzel, J., Walter, I. and Matus, I., (2017). Bioabsorption 
and Bioaccumulation of Cadmium in the Straw and Grain of Maize (Zea mays L.) in Growing Soils Contaminated with Cadmium in Different Environment. International Journal of Environmental Research and Public Health, 14(11), 1399.

Roberts, J.R., Karr, C.J., Paulson, J.A., Brock-Utne, A.C., Brumberg, H.L. and Campbell, C.C., \& Wright, RO (2012). Pesticide Exposure in Children. Pediatrics, 130(6):1765-1788.

Robson MG, DerMarderosian AH. (2012) Chapter 19. Pesticides. In: Loyd V. Allen Jr (Editor). Remington: The Science and Practice of Pharmacy (2 Volumes) 22nd Revised Edition. Pharmaceutical Press; 22nd Revised edition. ISBN: 0857110624, 9780857110626.

Rodríguez, J. and Mandalunis, P.M., (2018). A Review of Metal Exposure and its Effects on Bone Health. Journal of Toxicology, doi.org/10.1155/2018/4854152.

Sabir, S., Akash, M.S.H., Fiayyaz, F., Saleem, U., Mehmood, M.H. and Rehman, K., (2019). Role of Cadmium and Arsenic as Endocrine Disruptors in the Metabolism of Carbohydrates: Inserting the Association into Perspectives. Biomedicine and Pharmacotherapy, 114: 108802.

Schafer, H., (2019). South Asia: A Bright Spot in Darkening Economic Skies. World Bank Blog (End Poverty in South Asia).

Shelef, O., Weisberg, P.J. and Provenza, F.D., (2017). The Value of Native Plants and Local Production in an Era of Global Agriculture. Frontiers in Plant Science, 8: 2069.
Sodango, T.H., Li, X., Sha, J. and Bao, Z., (2018). Review of the Spatial Distribution, Source and Extent of Heavy Metal Pollution of Soil in China: Impacts and Mitigation Approaches. Journal of Health and Pollution, 8(17): 53-70.

Tegegne, H.A. and Phyo, H.W.W., (2017). Food Safety Knowledge, Attitude and Practices of Meat Handler in Abattoir and Retail Meat Shops of Jigjiga Town, Ethiopia. Journal of Preventive Medicine and Hygiene, 58(4): E320.

Thapa, K. and Pant, B.R., (2015). Pesticides in Vegetable and Food Commodities: Environment and Public Health Concern. Journal of Nepal Health Research Council.

Thielecke, F. and Nugent, A.P., (2018). Contaminants in Grain-a Major Risk for Whole Grain Safety? Nutrients, 10(9): 1213.

Thompson, L.A. and Darwish, W.S., (2019). Environmental Chemical Contaminants in Food: Review of a Global Problem. Journal of Toxicology, ID: 2345283

Tie, X., Huang, R.J., Dai, W., Cao, J., Long, X., Su, X., Zhao, S., Wang, Q. and Li, G., (2016). Effect of Heavy Haze and Aerosol Pollution on Rice and Wheat Productions in China. Scientific Reports, 6: 29612.

Tong, Y.U. and Wenjie, S.U.N., (2015). Who Will Feed the Giant?-Chinese Pollution and Grain Crisis. Iranian Journal of Public Health, 44(10): 14201421.

Zhang, X., Zhong, T., Liu, L. and Ouyang, X., (2015). Impact of Soil Heavy Metal Pollution on Food Safety in China. PLOS One, 10(8): 0135182. 